Keirl, S., (2015), 'Against Neoliberalism; For Sustainable-Democratic curriculum; Through Design and Technology Education', in Stables, K. \& Keirl, S., (Eds.), (2015), Environment, Ethics and Cultures: Design and Technology Education's Contribution to Sustainable Global Futures, pp, 153-174, Sense, Rotterdam.

..FINAL DRAFT

STEVE KEIRL

\title{
AGAINST NEOLIBERALISM; FOR SUSTAINABLE-DEMOCRATIC CURRICULUM; THROUGH DESIGN AND TECHNOLOGY EDUCATION
}

The educational point of the public school curriculum is understanding, understanding the relations among academic knowledge, the state of society, the processes of self formation, and the character of the historical moment in which we live, in which others have lived, and in which our descendants will someday live. It is understanding that informs the ethical obligation to care for ourselves and our fellow human beings, that enables us to think and act with intelligence, sensitivity, and courage in both the public sphere - as citizens aspiring to establish a democratic society - and in the private sphere, as individuals committed to other individuals. (Pinar, 2004, p. 187)

Children born around the beginning of this Century, now at school, have futures of a most uncertain kind. The qualitative range of scenarios is formidable. Any curriculum today has a duty to serve all children well wherever they are on the planet. The curriculum that serves only a localised group of children is both a selfish curriculum and one that disempowers those children it purports to serve. For its contribution, Design and Technology (D\&T) has a comprehensive role to play for all students everywhere (rather than a restricted role for only some students). In a related chapter I have talked of the learner-Bildung relationship working for the common good of both the student and the (global) community. I have also argued the ethical inter-dependence of sustainability, democracy and education - that they speak to, for, and of, each other ethically. To move from an ethical framing towards practical action in education calls for curriculum considerations. In this chapter I argue a case against the current dominant 
STEVE KEIRL

neoliberal ideology and try to show how D\&T, while enmeshed in that agenda, can also act to subvert it by working towards a sustainable-democratic D\&T curriculum. This begs serious questions for curriculum designers but most especially for teachers.

\section{EDUCATION AND NEOLIBERALISM}

Curriculum cannot be understood as something apart from its socio-political context so it is necessary to describe something of that context. In particular, the aggressive Western global agenda being advanced warrants attention because of its influence across sustainability, communities and education systems alike. Once this dominant agenda is critiqued, it becomes possible to (re)consider Design and Technology curriculum's potential for shaping sustainable global futures.

The marriage of industrialism and capitalism over the past 200-plus years has cost the ecosphere deeply. The mid-20 ${ }^{\text {th }}$ Century saw Leopold (1949) and Carson (1962/2002) articulate serious environmental concerns. Since the 1970s, the concepts of 'sustainability' and 'sustainable development' gained currency with the latter now recognised as operating across four domains - the ecological, the economic, the political, and the cultural. Thus, holistically understood, 'sustainable futures' must accommodate multiple, interdependent domains. To address only one domain is to negate the others.

Concurrently, since the 1980s we have witnessed the development of ever more radical forms of capitalism described in such intentionally benign language as the 'market economy' (after Galbraith, 2004/2005) and accompanied by the seemingly innocuous 'knowledge society' and 'lifelong learning', but nonetheless driven by central motives of growth and profit. The 1990s witnessed the advent of globalisation, initially understood as an economic phenomenon but now accepted as being multi-faceted (Ong \& Collier, 2005).

Also since the $1980 \mathrm{~s}$, the minority Western world has driven the neoconservative or neo-liberal project with its particular brand of capitalist imperialism, that is, a singular and aggressive form of capitalism designed (sic) to be the 'right' one for all nations to adopt. ('Nations' is a multivalent concept here, being variously used to refer to governments, geographical delineations, collectives of people/cultures, and so on. Globalisation in its various forms is testing the concept of the nation quite severely.) Under neo-liberalism the 'market' and market values are paramount and a global monoculture is the aim. Here, environments, cultures and alternatives come under threat. Privatisation is to replace (public) ownership-in-common, governments' capacities to control economies or state interests are weakened, price controls evaporate, and public voice or criticism is marginalised. Ominously, any activity or organisation operating on principles of altruism, community or cooperation is deemed a target for criticism and derision, if not destruction. 


\section{Giving democracy a bad name}

What has also been engineered is a conflation of the term democracy with a particular interpretation of economics in order to colonise political systems to the ends of exploitative profit-seeking and cultural suppression. Once this conflation is established it makes it harder to argue against the economic-environmental case without being accused of being 'against democracy'. Especially important to question are the languages and codes (readily promoted by compliant media) used to reposition all people as consumers rather than as citizens. Under such powerful conditions any care we might have for an ethically grounded triad of democracysustainability-education is seriously tested.

For neoliberals, the world in essence is a vast supermarket. "Consumer choice" is the guarantor of democracy. In effect, education is seen as simply one more product like bread, cars, and television... Thus, democracy is turned into consumption practices...the ideal of the citizen is that of purchaser. The ideological effects of this position are momentous. Rather than democracy being a political concept, it is transformed into a wholly economic one.' (Apple, 2001, p. 39).

From an outsider's perspective, failing to understand the history of this democracy-market conflation to which the Western populace has been subjected could reasonably lead to the conclusion that 'democracy' is a bad thing. By association, neoliberalism's attempts to re-model the world in its particular image and doctrines also heightens concerns for democracy's co-dependents: education and sustainability. In these neoliberal circumstances, democracy is corrupted, education is corrupted, and none of the four domains of sustainable development is sustainable.

Neoliberalism's effective promulgation depends on a combination of blunt rhetoric, subtle influence, and manipulation via a compliant media as well as through an integrated strategy of shaping political policies in ways that advance the ideology. For the success of this strategy, having a public comprising critical, debating, questioning citizens (all key to sustainable democratic life) is not helpful. If a climate of suppression of opinion, control of speech and protest, and derision of criticism is created to subvert opposition then democracy withers. Knowingly or otherwise, education and educators play their part in this.

Smith (2003) draws attention to the dangers of our being 'bought' by comfortable sloganism and the uncritical perpetuated myths of neoliberal ideology. He cautions that we ought heed history to attend to the future: 'Especially dangerous is the historical amnesia suffered by those claiming "the road ahead" (Bill Gates), that history has come to an "end" (Francis Fukuyama), or that "there is no alternative" (Margaret Thatcher).' (Smith 2003, p. 37. My italicised adaptations.) And, as Saul (1995) points out, when we are faced with seemingly insurmountable global problems, there is something appealing about any system that advocates a single-message one-shot solution because the express alternative is uncomfortable debates and difficult decisions. 'It is ideology that insists upon 
STEVE KEIRL

relentless positivism. That's why it opposes criticism and encourages passivity.' (Saul, 1995, p. 38). Dumbing-down - a major educational issue for democratic sustainability - happens partly because of poor education but as much because the very challenge of challenging means personal discomfort.

Smith (2003) offers an excellent critique of neoliberalism's impacts on education which, unfortunately, cannot be adequately reported here. He articulates the conditions and agenda that have been assembled to re-form education in the ideological mould. In 2003 he talked optimistically of, '...conditions that may be emerging for a new kind of global dialogue regarding sustainable human futures.' (Smith 2003, p. 35) but my deep concern remains today around the continuing lack of comprehensive curriculum dialogue in the public arena, in teacher education and in schools. Now, more than ever perhaps, new and vibrant dialogue can be reimagined and supported by ethically-framed Design and Technology curriculum discourse.

Drawing on international research, Smith (2003) shows how '... the application of neo-liberalist principles has resulted in a host of actions designed to change both the nature and delivery of educational work.' A selection includes: the portrayal of public education as 'failing'; the commercialisation of education with accountability through outcomes or product-based measures; the creation of competition between, schools, teachers, districts and, now, countries; privileging privatisation; prioritising accounting over pedagogical need; 'assaulting teacher unions'; false decentralisation with curriculum control remaining with governments; curriculum determination by non-education groups (national and international) to shape and control labour markets internationally; separating teachers' pedagogical judgements from educational management issues; and, '...pressurizing governments...into accepting these actions as a condition for joining... international trade cartels...' (All adapted from Smith, 2003, p. 38)

But this is not all. He nominates three actions which warrant Design and Technology's particular attention: tying educational financing to technologised instruction and the privileging of science and technology subjects to serve global industrial competitiveness; adopting a human capital resource model for the production of workers to match markets; and, '(I)nvoking the language of life-long learning to abate concerns about the end of career labor (expect to lose your job frequently, and reskill, as companies perpetually restructure to remain globally competitive)'. (Adapted from Smith, 2003, p. 38). Calls for a 'skilled workforce' are nothing new (Whitehead, 1917/1962; Penfold, 1988) but a skilled workforce is not necessarily an educated one. It matters to differentiate between general education in the compulsory years of schooling for all future citizens and any specialised (for example, vocational) education. We might also heed Sennett's (2008) reminder of: the long history of low social value attributed to craft skill in Western society; the inequitable remuneration of skilled workers; the maintenance of the class divisions imposed on such workers; and, the internationalisation of cheap labour and expertise.

Neoliberalism betrays democracy's good name and education has been colonised ideologically to play its part. Fortunately, voices of resistance have been 
clarion: Freire, (1972); Apple, (1979); Lyotard, (1979/1984); Giroux, (1983); and, Simon, $(1985 ; 1988)$. If an ethics of democratic practice, as a dimension of sustainable futures, is our aim, we might question whether the same old game is worth playing.

\section{CURRICULUM IN PERSPECTIVE}

Despite the need, this chapter cannot offer more than a brief overview of curriculum history and theory. However, a few key aspects should be noted. We can start by saying what curriculum is not. It is not a syllabus - which is a prescriptive statement of what is to be taught. Nor is a curriculum simply an aggregation of subjects. Nor is it necessarily what a government curriculum statement or policy says so, apart from the intended curriculum, the hidden curriculum and the actual curriculum exist too. While curriculum is an intentional act towards the young in society, as with most technologies, unintended consequences occur. Despite state policy or schools' aims, there are always multiple values, positions, and unspoken messages at play. The hidden curriculum is pervasive, is values-rich, and can operate positively or negatively. As a result curriculum as a whole is political and contestable. 'Curriculum policies and actions are never simple. There are often many different players with widely divergent priorities. Sometimes a seemingly simple curriculum decision becomes highly controversial. Some controversial issues in curriculum never die - they just reappear in slightly different guises.' (Marsh, 2005, Sleevenote)

Attempts at defining 'curriculum' are problematic but can be helpful if properly contextualised. Any comprehensive curriculum studies primer (e.g, Marsh \& Stafford, 1988; Print, 1988/1993; Smith \& Lovat, 2006) illustrates over a hundred years' worth of interpretations of 'curriculum'. Certainly, comprehensive interpretations get nearer the issues at hand. For example: 'The curriculum is all those discursive practices which affect what and how students learn, and what and how teachers teach.' (Reid and Johnson, 1999, p. ix). For another Australian curriculum thinker, curriculum was: '...the ultimate realisation for a complex enactment involving global, national, state, school, community, teacher and student actors, in terms of what students come to think, believe, know and do.' (Boomer, 1991/1999, p. 124). The spectrum of curriculum theorisations broadens again with, for example: Freire, (1972) on intentionality as consciousness; Morris (1966/1990) on existentialism; and Pinar (2004) on Bildung and autobiography. Curriculum articulations that valorise intentionality, existence, consciousness, and ethics offer qualitatively different opportunities for education for sustainable futures than does any instrumentalist device.

\section{Curriculum arrangements}

At a rather uncritical level, curriculum discussions pivot around how 'knowledge' and practices are organised in schools - usually understood as subjects, with distinct identities in secondary school settings. While a richer, integrated 
STEVE KEIRL

curriculum has run in primary schools, we now witness worrying moves to establish (and test) subject-based curricula in that sector too. Beyond the orthodox and with long histories are alternative curricular models such as Steiner-Wahldorf, Montessori, and home-schooling. Curriculum frameworks have also been established which nominally reduce the numbers of subjects into loose amalgamations organised into learning areas. Along with such arrangements have been outcomes or capabilities curricula which have focussed on the attributes of students themselves as well as particular epistemological content. South Australia's (DETE, 2001) Essential Learnings of: communication, futures, identity, interdependence, and thinking illustrate the capabilities approach. (For this book's purposes, other candidates readily suggest themselves, for example: sustainability, design and ethics.)

In addition to this technical analysis of curricula, Print (1988/1993) offers six conceptions or orientations of curriculum, namely: academic-rationalist; cognitive processes; humanistic; social reconstructionist; technological (based on efficiency of learning using technologies); and, drawing freely from across these, teacher and curriculum developer eclectic derivatives. Of these, the (competitive) academicrationalist is the prime educational instrument of the neo-liberal project and is grounded in orthodox subjects, hierarchically ordered. Having historic roots in the schooling of an elite has not translated well into industrial age curricula let alone for postmodern conditions (Lyotard, 1979/1984) celebrating multiple knowledges and recognising competing social, political and cultural power relations. Whose knowledge is valorised and how it is shared matters. Today, multiple resistances to the dominant, culturally embedded, subject-based curriculum (which, arguably, has also been an instrument of imperialism) are met with monological neoliberal calls for 'back-to-basics' education.

Not only are subjects attributed a hierarchy of value; but they are accompanied by teacher-centred, classroom-based pedagogy; individualised learning; and, formal competitive assessment (Johnson \& Reid, 1999). Such models advance the cultural transmission of 'the canon' (particular and culturally valorised knowledge) as opposed to '...higher-order and generic skills: communication, problem-solving, planning, decision-making, and so on. The former view is taken to be characteristic of social conservatives, while the latter is associated with social reform.' (Wilson, 2004/2005, p. 86).

Social re-form (as social justice) is not neoliberalism's purpose. Rather, people are to con-form to certain economic values and accept the positioning of persons as human capital. Here, government is by experts and elites and the state works to constrain social change and any threat to 'governance by the marketplace'. The individual is responsible for their own success and wellbeing while the curriculum is to create an elite of well-educated economic and political leaders, and a mass labour force, skilled and otherwise, to support the market. By contrast, a socially critical approach (or ideology) centres on the human and humans-as-persons capable of cooperative social progress. Here social interaction and participatory democracy are highly valued and economic and technological decision-making are held open to democratic ownership and control. The curriculum serves the 
common good by developing a critically reflective citizenry that participates in change for better and more equitable provision for all.

\section{Democracy cannot be left to look after itself}

'If the schools of a democratic society do not exist for and work for the support and extension of democracy, then they are either socially useless or socially dangerous.' (Mursell cited in Beane \& Apple, 2007, p. 26). I have used this champion of music education's explicit words because they remind us to care for democracy in two ways: maintenance and vigilance. That is, to look after democracy sustainably. To maintain the democratic vision or the ethical values that constitute democracy is the greatest defence against either democracy's erosion from within or attack from beyond. The fact that Mursell was writing sixty years does not mean that democracy was dead then, nor that is now, nor that it was a hundred years ago when Dewey (1916/1966) wrote Democracy and Education. Continuous vigilance is crucial.

As key agents of democracy, curricula have dual roles to play: at once both educating about democracy (serving democracy) as well as being democratic in their conduct (themselves democratic). The same is true of education for sustainability. Once we see (and critique) democratic education as both servant and conserver we realise how inclusive it can be. Such a curriculum, grounded in ethics, offers far more than the reproduction of established orthodoxies and (socially decontextualised) subjects. '...(T)he role of schools is to develop the capabilities of all students to the fullest extent possible for productive participation in our society. A stratified curriculum, such as one that is divided on the basis of vocational or academic 'aptitude', is fundamentally undemocratic because it aims to develop capabilities unevenly and related to particular roles in life...' (Reid, 2004/2005, p. 97). A curriculum that is democratic does not, in the compulsory years of schooling, discriminate amongst its constituents. It is inclusive and broad and any loss of curriculum breadth is a potential loss of ethical depth.

\section{Education-enculturation-socialisation-indoctrination}

'Teaching the skills of reasoned deliberation remains the educational aim most distinctively critical to a democratic society of free and equal citizens.' (Gutmann, 2003, p. 407). Since this is also the core requirement of ethical coexistence and sustainable global futures how can we ensure that it happens? To talk of curriculum as cultural reproduction or as maintenance of cultural norms is highly problematic in a multicultural society let alone in the multicultural world. Towards what should we enculturate our students - not least if the answer is contradictory to good ethical practice, democratic life and sustainable futures? Capacities to reason deliberatively are certainly needed.

In the absence of public consultation around the creation and adoption of any technologies, what role (other than, at best, socialisation) is left for education? Democratic participation in technological decision-making is minimal (Sclove, 
STEVE KEIRL

1995; Keirl 2006) so technologies seem no more than objects for (undemocratically determined) adoption. Thus people and learners are deterministically socialised towards technologies and systems without any critical or ethical discussion.

Alongside such scenarios of enculturation and socialisation, lurks indoctrination - an enemy of democracy. In a climate of ideology, passive learning, passive media consumption, and greenwashing, teacher-education today must include, as it used to, the study of indoctrination. White (1967) highlights the need for people/learners: being given the fullest possible picture around any issue; being given an education to weigh up issues; and, having the political space to enact their conclusions - whether by debate, resistance or activism. When such criteria are not met indoctrination by default results from uncritical education, and democracy atrophies.

\section{SUSTAINABLE-DEMOCRATIC CURRICULUM CONSIDERATIONS}

Are curricula working from vision-led orientations of sustainable global futures or are they consolidating the destructive status quo? If neoliberalism is the worsening global problem of the last thirty-plus years then orthodox curricula are part of that problem. Barlow \& Stone (2005) ask: 'How do we cultivate in children the competencies of heart and mind that they will need to create sustainable communities? How can we design schools as "apprenticeship communities" that model the practice of living sustainably?' (Barlow \& Stone, 2005, p. 1). Kahn (2009), draws on Jickling's concerns about '...the apparently instrumentalist and deterministic nature of education for sustainable development...(and how its)...tendency as a field to date is to treat education as merely a method for delivering and propagating experts' ideas about sustainable development, rather than as a participatory and metacognitive engagement with students over what (if anything) sustainable development even means.' Kahn, 2009, p. 531). From such a critique, epistemological, pedagogical and democratic concerns arise. Also absent is any suggestion of anticipating and engaging with the future in visionary ways that refute determinism and instrumentalism.

The arguments that Western education remains thoroughly unsustainable have never been stronger. Despite considerable efforts by teachers, activists, curriculum theorists and others to bring about more critical-democratic forms of education, there has remained a stubborn resistance to change. Boomer documents the 'massive inertia in education' and how little has changed pedagogically over a 100year period (Boomer, 1989/1999, p. 78). If change is to be achieved, what might be appropriate considerations for sustainable curricula? Clearly there is a need to move away from academic-rationalist models and, while some ground has been gained in this direction, the pressures to maintain the traditional, Western, competitive, curriculum are stronger than ever. 
Ethos

Rather than any 'blueprint for change' it is perhaps more helpful to express educational intentions as an ethos that speaks ethically, democratically and sustainably. This is not about what is to be taught but is about creating and maintaining an environment in which (after Dewey, 1916/1966; Bruner, 1960; Pinar, 2004) experience deepens understanding. Curriculum and learning can be led by vision towards better worlds and pursuing questions like 'How could the world be?' (on possibilities); 'How should the world be? (on ethics) and 'How would the world be if...?' (on imaginings). Similar to, but not the same as vision is curriculum orientation toward foresight enacted through recognising intention; developing capacities to act upon the world; taking care; understanding risk and precaution; and, (of course) designing.

Curriculum and learning could be framed by such thinking as Schumacher's three metaphysical ideas: i) levels of being or grades of significance for helping understand our place in relation to all else in the universe; ii) transcendence of opposites to overcome the ways orthodox distributions of knowledge are dichotomised; and, iii) ethics as essential to our values-clarification. 'Education which fails to clarify our central convictions is mere training or indulgence.' (Schumacher, 1973/1974, p. 83). Similarly, curriculum might take an existential orientation by investigating histories, presents and futures across the four realms of co-existence, of how we/students be-with: other humans; other species; the planet; and, technologies. (Keirl, 2010). Such investigations help develop students' rapport, empathy with and respect for 'the other' - in total, an ethics of care.

When adopting this curriculum ethos, teaching is not privileged over learning, and content is never the principal organising curriculum concept. Furthermore, the hidden curriculum is itself a site of critique and activism as democratic practices. Finally, the nature and purposes of any assessment activities must be seriously critiqued for how they privilege the ethos and the learners above any systemic functions.

\section{Learners}

In any sustainable-democratic curriculum all members of the school community and the related broader community are co-learners who develop understanding of the differences amongst transmissive, transactional and transformative models of education; amongst cooperation, collaboration and competition; as well as those amongst consumption, wellbeing and production. This facilitates education as critically experienced process rather than administered (re-)production in shaping the learner. The growth of the person as global thinker and citizen is key. This is the person as both individual and as participating member of community and society. This growth is lifelong and is understood as such by student and society alike perhaps as a reconceptualisation of the learner in the spirit of Bildung which '...grows out of an inner process of formation and cultivation, and therefore constantly remains in a state of continual Bildung.' (Gadamer, 1975/2004, p. 10). 
STEVE KEIRL

It is both sustainable and sustaining. Bildung not only develops the critical-ethical self but it also develops society in a manner of ever self-questioning in order to 'build better' for the common good.

\section{Knowledge/s and the sustainable-democratic curriculum}

Epistemology is a complex and contested field. Once 'knowledge' is restricted to mean traditional notions of facts, content and subjects (Freire's, [1972] banking concept) it can be used politically and instrumentally both to dictate curriculum form and to apportion the quality of learning inequitably. As Lyotard (1979/1984) and postmodernism have shown, there is not a grand narrative of singular knowledge but multiple knowledges and multiple ways of knowing. Thus the sustainable-democratic curriculum must be articulate not only in what it means by knowledge/s but also in how knowledges come to be and, importantly, whose interests are being served by the selected knowledges engaged by learners.

Drawing on critical theory (Habermas, 1971) highlights the way users and producers of knowledge have differing and competing 'interests' in that knowledge and how many learners do not have all of the interests met when, ethically and democratically, they should. The three knowledge interests are the technical, the practical-hermeneutic, and the critical-emancipatory. The first accommodates factual knowledge of the formal scientific kind and is what has shaped the dominant, traditional curriculum. The practical-hermeneutic knowledge interest facilitates meaning-making and understanding (Pinar, 2004) is deepened. Here, knowledge is developed in new ways and in new situations by the learner. Meaning is made culturally, socially and politically, that is, context plus appliedknowledge-as-experience leads to understanding. The critical-emancipatory interest frees the learner 'to be' in the world in ways that are reflective, emancipatory and fulfilling. The idea of the autonomous but engaged citizen emerges.

How, then, might curriculum move away from the subject-based knowledge segregation model? A well-established concept is that of curriculum integration, but why has it not been universally adopted? An illustration comes from UNESCO who, introducing the United Nations Decade of Education for Sustainable Development (DESD), sought: '...to integrate the principles, values and practices of sustainable development into all aspects of education and learning, in order to address the social, economic, cultural and environmental issues we face in the $21 \mathrm{st}$ century.' (UNESCO, 2005). Implicit here is an assumption that the dominant model will readily accommodate sustainable development: a) wholeheartedly; b) deeply; and c) in ways that challenge the instances where 'subjects' might be at the heart of the problem. In this modeling, sustainability and ethics may gain a curriculum profile but, arguably, as a tokenistic add-on, marginal and barely visible. In such a situation the privileged curriculum, having to compete in international tables in some 'subjects', offers limited hospitality to something as rich as ESD. 
There have been some genuine proposals to redesign curricula in supportive sustainable-democratic ways. We can consider Boomer's (1991/1999) advocacy of a 'key concern' curriculum in which '...there will be promiscuous employment of any of the known human ways of processing, exploring and investigating, and use of any relevant fact, knowledge or concept...'. (Boomer, 1991/1999, p. 117). He re-positions subjects to 'serve' learning through the key concerns:

...knowledge and skill in the service disciplines would be built up as required in investigations of a kind of Brunerian spiral curriculum in which the key question is explored in ever more sophisticated depth....The curriculum would not be logocentric in the way that current school offerings tend to be. A major resource or 'text' for this curriculum would be "lived experience"...Global literacy (the capacity to 'read' the world), capacity to make and do, capacity to interact socially, and capacity to imagine, would be significant areas for assessing the success of the students. (Boomer, 1991/1999, p. 118)

Another aspect of knowledge consideration in the sustainable-democratic curriculum is to clarify the interplay of the quantitative and the qualitative. Rather than quantifying and weighing how much learners know and using assessment as a political and social sifting technology, we can consider learning quality in relation to knowledge. As Freire (2001) has put it, to know and to understand, we must 'know' that we are always '... unfinished. On the one hand this knowledge reveals to me my ignorance, but on the other hand, it reveals to me that there is much I may still come to know,' (Freire, 2001, p. 120). He refers here not only to how much there is to learn of our worlds (and those of others) but is alert to powerful forces too. He argues that 'critical consciousness' is needed whenever we receive information from media, government or business sources.

It is foundational that learners (students and those who educate them) are everreceptive to new or different ways of knowing. Maintaining humility toward new knowledge/s as well as respecting cognitive pluralism (understanding the mind as socially created and that knowledge can be represented and accessed in multiple ways) are two examples. Differently, Eisner, highly critical of technocratic and behaviourist models of knowledge reproduction and assessment in schools, advanced a rich aesthetics of curriculum. (Urmacher, 2001).

\section{Three curriculum characteristics: consciousness, discomfort and conversations}

If significant steps away from educational instrumentalism are to be taken, then we embrace three characteristics of critical curriculum design and practice. First, multiple senses of consciousness matter and we can recall Gadamer's Bildung and the value of self-reflection, self-critique and transformation. He shunned passive acceptance of some form of 'natural consciousness' and preferred to advance '...working consciousness (which) contains all the elements that make up practical Bildung: the distancing from the immediacy of desire, of personal need and private interest...' (Gadamer 1975/2004, p. 12). Additionally, curriculum curriculum 
STEVE KEIRL

design might embrace Gadamer's cultivated consciousness; Freire's critical consciousness; Schumacher's levels and degrees of consciousness; false consciousness; in their respective ways, material consciousness (Sennett, 2008; Bennett, 2010); and, altered consciousness (Keirl \& McLaren, 2013).

Discomfort matters because much of the content- and assessment-driven orthodox curriculum brings little intellectual discomfort for either learners or teachers. There is a psychological sense of disequilibrium when learners move from one mental model to another (Edwards-Leis, 2010) but it is the deeper discomfort that comes when the learner's or educator's world-as-known is brought into question. Such discomfort comes when personal values are tested, when new ways of being-with the world and with others are encountered, and when challenges to the status quo are undertaken. Discomfort is also the companion of risk-taking and creativity. In all such situations learners are moving away from the ostensibly known, not to the unknown, but towards deeper understanding and to new knowings that are always provisional and uncertain. Education in, and for, intellectual discomfort is a characteristic of any sustainable-democratic curriculum. Kincheloe (2008/2010), for example, in developing his 'critical complex epistemology' puts things thus: 'This epistemological conversation cannot be separated from the future of the human species. Thus, it percolates into the depths of our humanity, our being in the world, raising disconcerting questions that offend individuals who have bought into some form of authoritarianism - whether its source is religious, political, or philosophical is irrelevant.' (Kincheloe, 2008/2010, p. 58).

Which opens up a third characteristic of critical curriculum practice - that of conversations (a term that, for convenience, I use rather loosely as signalling conversation, dialogue, discourse and dialectic). The primary use of the term is exemplified in Pinar's (2004) articulation of curriculum as complicated conversation. That is, there are no instant solutions or curriculum blueprints. If complexity describes the problem, if change is necessary, and there are multiple actors at play, then conversations must engage ideologies, principles, values, issues, and more.

Learners' conversations are a part of this too. Drawing on Freire, dialogic, dialectic pedagogy is the key to an active, engaged citizenry and such dialogue should not be determined from the 'top down', transmissively nor should such pedagogy be passive. 'Banking education resists dialogue; problem-posing education regards dialogue as indispensable to the act of cognition which unveils reality.' (Freire, 1972, p. 56). As Gadotti (1994) reports: 'In Paolo Freire's conception, dialogue is a horizontal relationship. It is fed by love, humility, hope, faith, and confidence...(He) refers to the experience of the dialogue when insisting that democracy should be practiced in public schools "It's necessary to have the courage to make democratic experiments".' (Gadotti, 1994, p. 50). When Barnes (1976) investigated the significance to learning of students' personal conversations he noted that '...the desire to communicate with others plays a dynamic part in the organising of knowledge.' (Barnes, 1976, p. 91) and he cites Esland's view of 
children being 'world-makers' rather than 'world-receivers'. (Barnes, 1976, p. 115).

Saul (1995) discusses how, despite our having considerable knowledge of the challenges facing the world, we behave quite unconsciously towards those challenges. His concluding remarks illustrate the three sustainable-democratic curriculum characteristics:

The virtue of uncertainty is not a comfortable idea, but then a citizen-based democracy is built upon participation, which is the very expression of permanent discomfort. The corporatist system depends upon the citizen's desire for inner comfort. Equilibrium is dependent upon our recognition of reality, which is the acceptance of permanent psychic discomfort. And the acceptance of psychic discomfort is the acceptance of consciousness. (Saul, 1995, p. 195)

\section{Pedagogy}

Pedagogy is as open to critique as any other key curriculum consideration for how it enables or inhibits sustainable and democratic education for preferred global futures. For Kahn (2009): 'Tomorrow's sustainable society - one that sustains all life, and not just its most powerful elements - if reliant upon education, will require a pedagogical revolution equal to its present socio-economic counterpart.' (Kahn, 2009, p. 526). More recently, he builds on Freire's critical pedagogy, articulating a radical ecopedagogy that cannot be reduced to environmental education, and showing how un-critical practices merely feed the neoliberal project:

...here environmental literacy has not only been co-opted by corporate state forces and morphed into a progressively-styled, touchy-feely method for achieving higher scores on standardized tests...but in an Orwellian turn it has come to stand in actuality for a real illiteracy about the nature of ecological catastrophe, its causes, and possible solutions. (Kahn, 2010, p. 9)

In line with a grounded, vision-led approach, Giroux (1983) advanced the centrality of ethics to critical pedagogy and argued for a '...radical pedagogy...informed by a passionate faith in the necessity of struggling to create a better world. (And for this)... .radical pedagogy needs a vision - one that celebrates not what is but what could be, that looks beyond the immediate to the future and links struggle to a new set of possibilities. This is a call for a concrete utopianism.' (Giroux, 1983, p. 242). Pedagogically, we can align his advocacy for 'creative risk-taking' with Freire's argument that: 'Banking education treats students as objects of assistance; problem-posing education makes them critical thinkers.' (Freire, 1972, p. 56); and Capra's case for '....an experiential, participatory, and multidisciplinary’ pedagogical approach. (Capra, 2005, p. xiv). 
STEVE KEIRL

\section{DESIGN AND TECHNOLOGY'S CURRICULUM PLAY}

I have argued that the impetus and ideological commitment of the neoliberal project is a major global concern for sustainable futures and that education is intertwined, by design, with this project. Implicitly, D\&T curriculum is a part of this and its players have some choices to make. Because Technology itself is complex, pervasive and generally not well understood, the need has never been greater for a rich education in the phenomenon (Keirl, 2006). But what constitutes a rich D\&T education leads to making some important and difficult decisions. We can identify the ways that D\&T serves to further non-sustainable, anti-democratic, unethical practices in pursuit of growth and profit and we can act to resist and change those practices, or we carry on as normal doing what 'seems obvious'.

Just because the phenomenon of Technology is complex does not mean that education and curriculum cannot handle that complexity. However, some basic questions apply. In what ways is D\&T constrained by the neoliberal agenda to serving a largely vocational role in education? Conversely, how can D\&T serve all students democratically and ethically? If curriculum were led by an ethical, futurefocussed, global vision how different might D\&T be and what curriculum role can it contribute? What if D\&T were constituted, as many have argued, as a form of literacy to be taught throughout the curriculum as well as in some D\&T identityshaping way such as a learning area or as a set of capabilities? Can D\&T be constituted primarily as a major contributor to an educated, ethical global citizenry rather than as a 'subject' devoted to 'skilling' for the uncritical adoption of technologies?

While D\&T can rightly feel aggrieved when it comes to its inequitable status with the so-called 'academic' elite of subjects, there can be some advantages. So long as the field is free from rigorous testing regimes and content specifications then greater curriculum self-determination can occur. Besides, why would such an invaluable but thoroughly under-appreciated aspect of curriculum want to be 'academic'? This is a hollow aspiration.

\section{Design and Technology ethos}

Once the focus moves to how D\&T serves the general education of all students-asfuture-global-citizens then a different D\&T ethos can emerge. So long as D\&T is to serve the economy, address (alleged) skills shortages, prioritise growth over sustainability, profit over environments, industries over communities, consumerism over citizenship, elites over social justice, and self-interest over the common good, it then lays itself open to most serious ethical critique. At best, it remains instrumental.

If, on the other hand, it takes the global democratic project to heart a different curriculum picture emerges. The field becomes liberated to educate holistically across the curriculum and even to offer innovative curriculum leadership to inform better practices. Design literacy and technological literacy need their share of curriculum air to breathe. To achieve this, teachers, curriculum workers and 
policymakers themselves will all have to consider their personal values and their political positions in order to act. To behave with apathy or passivity reinforces the status quo and helps the steamroller to crash on.

Layton (1994) showed us two decades ago that our (relatively new) curriculum field is highly contested amongst stakeholders. No longer can D\&T be dominated by the limited interests of economic instrumentalists or select professions. It is now overdue that we accommodate the interests of girls and women, multiple cultures, defenders of participatory democracy, sustainable developers, and, for an existential dimension, liberal educators too (after Layton, 1994). If the field is to move beyond its own equivalent of banking education (competency-style skill training) then it needs renewed identity and integrity - curriculum and public identity and curricular integrity - across all of epistemology, existentialism, critical pedagogy and ethics. As our understandings deepen of the nature of technological relationships and our realms of being-with the world, we see that there are indeed complicated conversations to be had.

\section{Learners}

Design and Technology learners are persons - not material to be worked on for economic consumption. For this reason alone, learners are considered before the discussion of knowledge or curriculum content that follows. Like all others with futures (persons, species, technologies, the planet) learners need understandings of ethics, sustainability, the very reasons for education, and what it means to be a responsible global citizen. If D\&T has a place in such a curriculum then it must work for its learners accordingly. If D\&T cannot meet these requirements then it has no part in the sustainable-democratic curriculum. As with all aspects of a critical curriculum for sustainable global futures, teachers and students are colearners, co-constructing and designing the curriculum through negotiation. Learners in such an environment develop, and contribute to, Bildung - everforming and re-forming themselves, communities and society. Here, not only does consciousness in all its senses develop but the student learns the right as a citizen '...to criticise, to reject conformity, passivity, inevitability.' (Saul, 1995 p. 39). Design and Technology can become a site for personal, cultural and political technological values clarification.

As with the total curriculum, instrumentally-conceived D\&T cannot properly contribute to democratic learning. However, a design-based, critical approach sees multiple learning opportunities arise. Knowledge is never a given. Personal knowledge creation happens when learners design because a commitment is made to research and to creativity. (Who 'knows' what might result?) Critical learning demands the questioning of ideas, thoughts, designs, of what is, and of what could be. Critical D\&T curriculum engages all of: imagination; creativity; technique; idealism; ethics; confidence; and, empathy. Learners' personal empowerment, identity and efficacy are all enhanced through rich (rather than an impoverished) Design and Technology. They learn about possibilities beyond their current location, time and knowledge. In all, the existential is respected, the capacity to act 
STEVE KEIRL

towards better worlds is realised, and sustainable-democratic understanding deepens.

\section{Seeking knowledge in Design and Technology}

In what I contend is the happy absence of a readily-identifiable body of knowledge for D\&T (despite those actively seeking it) the field had tended to express itself simply through skilling and vocationalism or through a thin epistemological blending of the knowing-that/knowing-how kind. While a major epistemological debate is needed, I argue that the 'body of knowledge' goal is a mirage and a distraction. (In part, this issue links with my deep personal concerns about the threat to quality D\&T by the so-called STEM agenda.)

Our field is, in essence, a doing field - ideally, doing-with-wisdom in the sustainable-democratic curriculum. It is about intentional acts on an ever-changing world and, while it does draw on existing knowledge, much technological activity is both provisional and speculative. Drawing on Boomer (1991/1999), 'subjects' such as maths and science can serve D\&T rather than dominating it.

Advancing such a position, a whole-curriculum design/technological literacy approach can permeate all years of general education. Such literacy applies both critical and ethical theory. In turn, D\&T as a constituent field of learning can be articulated through a series of verbs. This strongly theorised and proven-inpractice curriculum design (DETE, 2001; Keirl, 2002a\&b, 2004) saves D\&T from the heavier knowledge 'content' games but, crucially, positions learners at the centre of their education. Further, it readily facilitates and maintains the ethically grounded sustainable-democratic curriculum. Thus, the Habermasian knowledge interests informed a new curriculum:

Technological literacy can be viewed as having three dimensions, all of which are equally valid and important. All students benefit from all dimensions of technological literacy and must not be constrained in their learning to one aspect alone. The three dimensions are:

- the operational, through which students develop skills and competencies at a technical level to use materials and equipment in order to make products and systems (they learn to use and do);

- the cultural, through which students contextualise their learning in the world of designed and made products, processes and systems. They recognise the interdependence of technologies with people.....and they apply their technical learning in practical ways to realise designs and solve practical problems (they learn through technology); and,

- the critical, through which students are empowered to take a full and critical role as autonomous citizens in technological societies. They are able to make refined judgements about the worth of the intentions and consequences of technological products, processes and systems on themselves and others...(they learn about, and to be with, technology). (DETE, 2001) 
While this illustrates the curriculum intention, it is articulated in practice through three strands (as verbs, action words): Critiquing, Designing and Making which, too, are not only interdependent but must all be addressed if the holism of sustainable-democratic D\&T curriculum is to be realised.

Designing is to work with intention. It is neither about accident nor prescription. Designing is about choice-making and weighing up competing variables. It is values-rich, not values-neutral (as some argue technologies to be). It is about uncertainties and working with inadequate information and there is never a 'right answer', rather, there are only 'best defensible compromises'. Designing is a form of knowledge creation. Design, as noun or verb, is open to advocacy, defence and contestation. For all of these reasons, taught well, designing resists much orthodox education and orthodox technology education because the learner is key, transmissive teaching gives way to pedagogies of uncertainty, discomfort, critique and scepticism.

And in such a curriculum, Critiquing is a trait of 'continuous Bildung' for all. It is a way of thinking, acting and being. Critiquing is the purposeful, practical and metaphorical deconstruction and analysis of any product, process or system in order to expose the values and intentions behind designs, the unanticipated applications of technologies, and the relationships between people and technologies. As when designing, new meanings and knowledge emerge from critiquing and new realisations emerge for seeing, judging and living in the designed world.

\section{$D \& T$ and the three sustainable-democratic curriculum characteristics}

When critiquing, designing and making in Design and Technology education, ethical, democratic and sustainability values contestations arise. What can be openly celebrated is that these technological values contestations bring vibrancy, focus and quality to the sustainable-democratic curriculum. They are the concern of all curriculum players and are central to the learning of all learners. What they also highlight are their significance to consciousness, how discomfort is an educationally-managed reality, and the need for dialogue across the whole curriculum enterprise.

Because such a curriculum celebrates values contestation, the breadths of ethical and political spectra become visible. Conversations become paramount - from the policy-maker to the student - and ideally between both such parties too! This is a genuine application of curriculum as complicated conversation and it is through such conversations that discomfort occurs as values positions are explored, tested, learned, refined, and promoted. As an outcome, consciousnesses are heightened. All of this is a far cry from the banking concept of education because it centres on sustainable, democratic and preferred global futures as perpetual goals. One major difference is that education becomes ('should be' is the ethical claim) an end in itself and not a means or instrument of other ends. In the spirit of Bildung, growth, formation and becoming happen. This kind of (Design and) Technology education 
STEVE KEIRL

offers democratic societies a new, critical technological consciousness - one which can become a shared way-of-being considerate of worlds yet-to-be-realised.

\section{Pedagogy}

Another of the considerable advantages D\&T curriculum enjoys in the current dominant climate is that the pedagogical repertoire of teachers can be both rich and adventurous. Freed from restrictive assessment and curriculum prescriptions it becomes possible to use a future-focussed critical pedagogy (Freire, 1972; Darder et al., 2009; Kincheloe, 2008/2010; Kahn, 2010; Smyth, 2011) that advances sustainable-democratic futures through all of critiquing, designing and making. The responsibilities on learners when they design and critique, and when they defend the decisions taken when they make, are such that their democratic capabilities are heightened. Assessment accompanying such pedagogy is equally democratic and participatory - not mandated by an external scaling system operated in the name of standards or accountability and positioning the learner as statistic in international league tables rather than as person. In total, if D\&T curriculum is constructed and constrained technically it is also taught transmissively and uncritically. A values-rich curriculum demands an emancipated and emancipating pedagogy for learner and teacher alike. Such an ethically-based pedagogy is readily learner-centred but, importantly, it is also learner-as-futurebeing-and-citizen-centred. It serves the distant unknown, rather than what is already known.

\section{Teachers (with learners) at the core}

Noticeably perhaps, little has been said so far about those who are absolutely key to the success (or otherwise) of any curriculum. D\&T teachers, usually marginalised in mainstream educational research and discourse, are considered as central to the following concluding remarks.

The professional deskilling of teachers began in the 1980s (Apple \& Teitelbaum, 1986) and the metamorphosis to uncritical technical curriculum deliverer continues: '...standardised reforms have taken away teachers' time to think; and their imposed, prescriptive requirements have replaced creativity with compliance.' (Hargreaves 2003, pp. 82-83), and more recently:

...what is clearly being constructed through these neo-liberal manoeuvres is an identity of the "preferred" teacher - one who is dutiful, compliant, market responsive and uncritical of the circumstances and conditions around her especially in respect of what the neo-liberal agenda is doing to schooling and groups within it. (Smyth, 2011, p. 29)

The literature on the 'constructions' of the teacher is an extensive branch of curriculum studies. There is no universal meaning of 'teacher' whether viewed externally or amongst teachers themselves. Documenting some of the literature, Keirl (2009) identified a range including teacher as: worker (Reid, 1998); leader- 
learner (Lingard et al., 2003); ethical (Campbell, 2003); entrepreneur (Sachs, 2003); technician (Hextall \& Mahony, 1998); activist professional (Sachs, 2003); reflective practitioner (Schon, 1987); critical practitioner (Blackmore, 2002); socially critical (Smyth et al., 2000); continuing learner-worker (GroundwaterSmith et al., 2001). Smyth (2011) also references: '...teacher-as-bricoleur; teacher-as-improviser; ... and teacher-as-social activist...' (Smyth, 2011, p. 30. Italics added). A most significant contribution, recurrent in the literature, is Giroux's comprehensively theorised case for teachers as transformative intellectuals (Aronowitz \& Giroux, 1993).

Ultimately, the issues raised in this chapter hinge on Design and Technology teachers' personal identities and values determinations. Sustainable-democratic curricula are as key to sustainable global futures as instrumentally academicrationalist curricula are to neoliberalism and non-sustainable futures. Throughout, the issues are ethical and political. Teaching is a political act (Keirl, 2007) and Postman \& Weingartner's (1969/1971) thesis that teaching can be a subversive activity maintains its prescience. All of this is at once deeply challenging, discomforting yet can be liberating. Curriculum courage is needed for muchneeded curriculum conversations across classroom, community, policy-making and ideology.

Curriculum ceases to be a thing, and it is more than a process. It becomes a verb, an action, a social practice, a private meaning, and a public hope. Curriculum is not just the site of our labor, it becomes the product of our labor, changing as we are changed by it...It is an ongoing, if complicated, conversation. (Pinar, 2004, p. 188)

\section{REFERENCES}

Apple, M.W., (1979), Ideology and curriculum, Routledge and Kegan Paul, London.

Apple, M.W., (2001), Educating the "Right" Way: markets, standards, God and inequality, Routledge Falmer, New York.

Apple, M.W., \& Teitelbaum, K., (1986), 'Are Teachers Losing Control of Their Skills?' Journal of Curriculum Studies, Vol.18, No.2, pp.177-184.

Aronowitz, S., \& Giroux, H.A., (1993), Education Still Under Siege, $\left(2^{\text {nd }}\right.$. Edn.), Bergin \& Garvey, Westport, CT

Barlow, Z. \& Stone, M.K., (2005), 'Introduction' in Stone, M.K. \& Barlow, Z., (Eds.), (2005), Ecological Literacy: Educating our children for a sustainable world, pp. 1-8, Sierra Club Books, San Francisco.

Barnes, D., (1976), From Communication to Curriculum, Penguin, Harmondsworth.

Beane, J.A. \& Apple, M.W., (2007), 'The Case for Democratic Schools' in Apple, M.W. \& Beane, J.A., (Eds.), (2007), Democratic Schools: Lessons in Powerful Education, (2 ${ }^{\text {nd }}$ Edn.), pp. 1-29, Heinnemann, Portsmouth, NH.

Bennett, J., (2010), Vibrant Matter: A Political Ecology of Things, Duke University Press, London.

Blackmore, J., (2002), 'Speaking out for critical professionalism and education' in Curriculum Perspectives: the Journal of the Australian Curriculum Studies Association, (Sep. 2002), vol 22, No 3, pp.60-62.

Boomer, G., (1989/1999), 'Education and the Media - Makers or Mirrors? Dilemmas in the development of Australian culture' in (Ed.) Green, B., (1999), Designs on Learning: Essays on 


\section{STEVE KEIRL}

curriculum and teaching by Garth Boomer, pp. 71-81, Australian Curriculum Studies Association, Canberra.

Boomer, G., (1991/1999), 'Changing Curriculum', in (Ed.) Green, B., (1999), Designs on Learning: Essays on curriculum and teaching by Garth Boomer, pp.113-125, Australian Curriculum Studies Association, Canberra.

Bruner, J.S., (1960), The Process of Education, Harvard University Press, Cambridge, Massachusetts. Campbell, E., (2003), The Ethical Teacher, Open University Press, Maidenhead, UK.

Capra, F., (2005), 'Preface' in Stone, M.K. \& Barlow, Z., (Eds.), (2005), Ecological Literacy: Educating our children for a sustainable world, pp. xiii-xv, Sierra Club Books, San Francisco.

Carson, R., (1962/2002), Silent Spring, (40 ${ }^{\text {th }}$ Anniversary Edition), Mariner Books, New York.

Darder, A., Baltodano, M. P. \& Torres, R. D., (Eds.), (2009), The Critical Pedagogy Reader, (2 ${ }^{\text {nd }}$ Edn.), Routledge, London.

Department of Education, Training and Employment (DETE), (2001), South Australian Curriculum Standards and Accountability Framework (SACSA), URL: http://www.sacsa.sa.edu.au

Dewey, J., (1916/1966), Democracy and Education: An introduction to the philosophy of education, Free Press, New York.

Edwards-Leis, C.E. (2010). Mental models of teaching, learning, and assessment : A longitudinal study. $\mathrm{PhD}$ thesis, James Cook University. URL: http://eprints.jcu.edu.au/15182/

Freire, P., (1972), Pedagogy of the Oppressed, Penguin, London

Freire, P., (2001), Pedagogy of Freedom: Ethics, Democracy, and Civic Courage, Rowman \& Littlefield, Lanham, Maryland.

Gadamer, H-G., (1975/2004), Truth and Method, (2 ${ }^{\text {nd }}$ Edn.), (Trans. Weinsheimer, J. \& Marshall, D.G.), Continuum, London

Gadotti, M., (1994), Reading Paolo Freire, His Life and Work, SUNY Press, Albany, NY

Galbraith, J K., (2004/2005), The Economics of Innocent Fraud, Penguin, London

Giroux, H.A., (1983), Theory and Resistance in Education: A Pedagogy for the Opposition, Heinemann Educational Books, London.

Groundwater-Smith, S., Brennan, M., McFadden, M. \& Mitchell, J., (2001), Secondary Schooling in a Changing World, Thomson, Melbourne.

Gutmann, A., (2003), 'The Authority and Responsibility to Educate' in Curren, R., (Ed.), (2003), A Companion to the Philosophy of Education, pp. 397-411, Blackwell, Oxford.

Habermas, J., (1971), Knowledge and Human Interests, Beacon, Boston.

Hargreaves, A., (2003), Teaching in the Knowledge Society: Education in the age of insecurity, Open University Press, Maidenhead, UK.

Hextall, I. \& Mahony, P., (1998), 'Effective Teachers for Effective Schools' in (Eds) Slee, R., Weiner, G. \& Tomlinson, S., (1998), School Effectiveness for whom? Challenges to the Effectiveness and School Improvement Movements, Falmer Press, London.

Johnson, B. \& Reid, A., (Eds.), (1999), Contesting the Curriculum, Social Science Press, Katoomba.

Kahn, R., (2009), 'Towards Ecopedagogy: Weaving a Broad-based Pedagogy of Liberation for Animals, Nature, and the Oppressed People of the Earth', in Darder, A., Baltodano, M. P. \& Torres, R. D., (Eds.), (2009), The Critical Pedagogy Reader, ( ${ }^{\text {nd }}$ Edn.), pp. 522-540, Routledge, London.

Kahn, R., (2010), Critical Pedagogy, Ecoliteracy, \& Planetary Crisis: The Ecopedagogy Movement, Peter Lang, New York.

Keirl, S., (2002a), 'Against the provincialism of customary existence: issues arising from the interplay of 'essential learnings', design and technology and general education' in (Eds.) Middleton, H., Pavlova, M., \& Roebuck, D. (2002), Learning in Technology Education: Challenges for the $21^{\text {st }}$ Century, Proceedings of the $2^{\text {nd }}$ Biennial International Conference on Technology Education Research, 5 -7 December 2002, Parkroyal Surfers Paradise, Gold Coast, Queensland, Australia. Centre for Technology Education Research, Griffith University, Qld.

Keirl, S., (2002b), 'A moment in Design and Technology curriculum development as a component of educational reform', in (Eds.) Pavlova, M. \& Gurevich, M., (2002), Proceedings of $1^{\text {st }}$ Biennial International Conference on Technology Education, 10-13 July 2002, Nizhny Novgorod, Russia. 


\section{AGAINST NEOLIBERALISM; FOR SUSTAINABLE-DEMOCRATIC CURRICULUM}

Keirl, S., (2004), 'Critiquing and Designing as Keys of Technological Literacy: matters arising from the meeting' in (Eds.) Middleton, H., Pavlova, M. \& Roebuck, D., (2004) Learning for innovation in technology Education: proceedings of the $3^{\text {rd }}$ Biennial International Conference on Technology Education Research, Vol. 2, pp. 91 - 98, Surfers Paradise, Australia, 9-11, Dec. 2004

Keirl, S., (2006), 'Ethical technological literacy as democratic curriculum keystone' in (Ed.) Dakers, J.R., (2006), Defining Technological Literacy: Towards an epistemological framework, pp 81-102, Palgrave Macmillan, Basingstoke.

Keirl, S., (2007), 'The politics of technology curriculum', in (Ed.) Barlex, D., (2007) Design and Technology - For the Next Generation: A collection of provocative pieces, written by experts in their field, to stimulate reflection and curriculum innovation, Nuffield Foundation, UK.

Keirl, S., (2009), 'Doing the odyssey in Neurath's boat: design and technology professional development journeys and teacher professional judgement.' in Jones, A.T. \& de Vries, M.J. (eds.), (2009), International Handbook of Research and Development in Technology Education, Ch.45, pp.541-554, Sense, Rotterdam.

Keirl, S., (2010), 'Critiquing and Designing as Thinking Tools for Technology Education for Sustainable Co-existence' in Hansen, R. \& Petrina, S., (Eds.), Proceedings of the Technological Learning and Thinking: Culture, Design, Sustainability, Human Ingenuity Conference, pp 531-540, Vancouver, BC, 17-19 June, $2010 . \quad$ URL: http://m1.cust.educ.ubc.ca/conference/index.php/TLT/2010/paper/view/57/5

Keirl, S. \& McLaren, S,V., (2013), 'Students as choice-makers: developing altered consciousness as an aspect of design and global citizenship literacy', in (Eds.), Reitan, J.B., Lloyd, P., Bohemia, E., Nielsen, L.M., Digranes, I. \& Lutnæs, I., Design Learning for Tomorrow: Design Education from Kindergarten to PhD: Proceedings from the 2nd International Conference for Design Education Researchers: (Vols. 1-4), (Design Research Society/CUMULUS the International Association of Universities and Colleges of Art, Design and Media, 14-17 May 2013, Oslo, Norway), Vol. 3, pp. 1611-1625, ABM-media/Oslo and Akershus University College of Applied Sciences, Oslo.

Kincheloe, J. L., (2008/2010), Knowledge and Critical Pedagogy: An Introduction, Springer, Springer.com.

Layton, D., (Ed.), (1994), 'A School Subject in the Making? The Search For Fundamentals', in Layton, D., (Ed.), (1994), Innovations in Science and Technology Education, Vol. V., pp. 11-28, UNESCO, Paris.

Leopold, A., (1949), A Sand County Almanac, and Sketches Here and There, Oxford University Press, New York.

Lingard, B., Hayes, D., Mills, M. \& Christie, P., (2003), Leading Learning: Making hope practical in schools, Open University Press, Maidenhead, UK.

Lyotard, J-F., (1979/1984), The Post-Modern Condition: A Report on Knowledge, Manchester University Press, Manchester.

Marsh, C. (Ed.), (2005), Curriculum Controversies: point and counterpoint 1980 - 2005, Australian Curriculum Studies Association, Deakin West, Australian Capital Territory.

Marsh, C. \& Stafford, K., (1988), Curriculum: Practices and Issues, ( ${ }^{\text {nd }}$ Edn.), McGraw-Hill, Sydney.

Morris, V C, (1966/1990), Existentialism in education: what it means, Waveland Press, Prospect Heights, Ill.

Ong, A. \& Collier, S.J., (Eds.), (2005), Global assemblages: Technology, Politics, and Ethics as Anthropological Problems, Blackwell, Oxford.

Penfold, J., (1988), Craft, Design and Technology: Past, present and future, Trentham, Stoke-on-Trent.

Pinar, W.F., (2004), What is Curriculum Theory? Routledge, New York.

Postman, N. \& Weingartner, C., (1969/1971), Teaching as a Subversive Activity, Penguin, Harmondsworth.

Print, M., (1988/1993), Curriculum Development and Design, ( $2^{\text {nd }}$ Edn.), Allen \& Unwin, St. Leonards, NSW. 


\section{STEVE KEIRL}

Reid, A., (1998), 'Regulating the education market: The effects on public education workers' in Reid, A., (ed) (1998), Going Public: Education Policy and Public Education in Australia, pp. 57-66, ACSA, Canberra.

Reid, A., (2004/2005), 'Challenging the dominant Grammars of an Undemocratic Curriculum' in Marsh, C. (Ed.), (2005), Curriculum Controversies: point and counterpoint 1980 - 2005, pp. 97-105, Australian Curriculum Studies Association, Deakin West, Australian Capital Territory.

Reid, A. \& Johnson, B., (1999), 'Contesting the Curriculum' in Johnson, B. \& Reid, A., (Eds.), (1999), Contesting the Curriculum, pp. viii-xvii, Social Science Press, Katoomba.

Sachs, J., (2003), The Activist Teaching Profession, Open University Press, Buckingham, UK.

Saul, J.R., (1995), The Unconscious Civilisation, Anansi, Toronto.

Schon, D. A., (1987) Educating the Reflective Practitioner: Toward a design for teaching and learning in the profession, Jossey-Bass, San Francisco, CA.

Schumacher, E.F., (1973/1974), Small is Beautiful, Abacus, London.

Sclove, R.E., (1995), Democracy and Technology, The Guilford Press, N.Y.

Sennett, R., (2008), The Craftsman, Yale University Press, New Haven.

Simon, B., (1985), Does Education Matter?, Lawrence and Wishart, London

Simon, B., (1988), Bending the Rules: The Baker 'reform' of education, Lawrence and Wishart, London

Smith, D.G., (2003), 'Curriculum and Teaching Face Globalization', in Pinar, W.F., (Ed.), (2003), International Handbook of Curriculum Research, pp. 35-51, Lawrence Erlbaum Associates, Mahwah, NJ.

Smith, D.L. and Lovat, T.J., (2006), Curriculum: Action on Reflection, ( ${ }^{\text {th }}$ Edn.), Thomson/Social Science Press, South Melbourne.

Smyth, J., (2011), Critical Pedagogy for Social Justice, Continuum, New York.

Smyth, J., Dow, A., Hattam, R., Reid, A. \& Shacklock, G., (2000), Teachers' Work in a Globalizing Economy, Falmer Press, London.

United Nations Educational, Scientific and Cultural Organisation, (UNESCO), (2005), United Nations Decade of Education for Sustainable Development (DESD),

URL: http://www.unesco.org/new/en/education/themes/leading-the-international-agenda/education-forsustainable-development/three-terms-one-goal/

Urmacher, P.B., (2001), 'Eliot Eisner' in Palmer, J.A., (Ed.), (2001), Fifty Modern Thinkers on Education: From Piaget to the Present, pp.247-252, Routledge, London.

White, J.P., (1967), 'Indoctrination' in Peters, R.S., (Ed.), (1967), The Concept of Education, pp177191, Routledge \& Kegan Paul, London

Whitehead, A.N., (1917/1962), Technical Education and its Relation to Science and Literature' in The Aims of Education and Other Essays, pp.66-92, Ernest Benn, London.

Wilson, B., (2004/2005), 'What We Mean By Knowledge?' in Marsh, C. (Ed.), (2005), Curriculum Controversies: point and counterpoint 1980 - 2005, pp. 86-88, Australian Curriculum Studies Association, Deakin West, Australian Capital Territory.

\section{Steve Keirl}

Department of Design

Goldsmiths, University of London 